\title{
RANCANGAN MODIFIKASI ALGORITMA AODV PADA MANET UNTUK MENINGKATKAN PERFORMANSI SKEMA ROUTING DAN DETEKSI KONGESTI (STUDI LITERATUR)
}

\author{
Arif Fadllullah \\ Jurusan Teknik Elektro Universitas Borneo Tarakan, Tarakan, Kaltara, Indonesia \\ e-mail: arif.fadlegmail.com
}

\begin{abstract}
AODV is one of the well-known reactive routing protocols on MANET that is built on routing requests. This protocol is widely used because of low routing overhead and high performance. However, sending data packets using conventional AODV often delay, when the routing path is interrupted as a result of the movement of nodes that change in the path. Therefore, this study proposes a modified AODV design that not only has the routing scheme feature of the main path chosen based on link throughput and minimum hop count, but also considers providing alternative paths when the link node is damaged or when the data packet queue exceeds the maximum capacity of a node until congestion status occurs at the node, especially to reduce packet delay delays that are prone to occur in conventional $A O D V$.
\end{abstract}

Keywords-AODV, Modification AODV, Link Throughput, Congestion Detection

Intisari-AODV adalah salah satu protokol reaktif routing yang terkenal pada MANET yang dibangun berdasarkan permintaan routing. Protokol ini banyak dipakai karena overhead routing yang rendah dan performa tinggi. Hanya saja pengiriman paket data menggunakan AODV konvensional seringkali terjadi delay, manakala jalur routing terputus sebagai akibat adanya pergerakan node yang berubah-ubah dalam jalur. Oleh karena itu, penelitian ini mengusulkan rancangan AODV modifikasi yang tidak hanya memiliki fitur skema routing jalur utama yang dipilih berdasarkan link throughput dan minimum hop count, tetapi juga mempertimbangkan penyediaan jalur alternatif saat link node mengalami kerusakan maupun saat antrian paket data melebihi kapasitas maksimal suatu node hingga status kongesti terjadi pada node, khususnya untuk mengurangi delay pengiriman paket yang rentan terjadi pada AODV konvensional.

Kata Kunci-AODV, AODV Modifikasi, Link Throughput, Deteksi Kongesti

\section{PENDAHULUAN}

Saat ini, internet telah menjadi salah satu bagian yang tidak terpisahkan untuk menunjang kebutuhan manusia dalam hal pengiriman data dan komunikasi jarak jauh. Agar dapat terhubung dengan jaringan internet, tidak hanya diperlukan perangkat yang memiliki network interface connection ataupun perangkat wireless mobile, melainkan juga harus memiliki perangkat penunjang, seperti access point dan router yang tersambung ke BTS (base station) infrastruktur internet melalui ISP (internet service provider) yang terdaftar. Tentu hal ini akan memakan biaya apalagi jika membutuhkan bandwidth yang besar untuk mengakses informasi dalam internet baik berdasarkan volume based maupun time based.

Kondisi tersebut memunculkan ide bagaimana manusia bertukar data atau informasi tanpa tersambung ke jaringan internet. Salah satu alternatif adalah memanfaatkan layanan wireless yang terpasang pada perangkat tertentu atau di kenal dengan istilah MANET (Mobile Ad Hoc Network). Metode ini berdasarkan fakta bahwa sekarang ini mudah sekali ditemukan perangkat berbasis mobile wireless, seperti laptop, tablet, note, hp, dan lain sebagainya dalam jangkauan yang saling berdekatan. Dengan MANET, perangkat tersebut dapat berperan sebagai host, router, dan forwarding packets sehingga dapat melakukan pertukaran data tanpa memerlukan base station yang tetap sebagai relay transmisinya. Syaratnya, partisipan dalam jaringan ini harus mau menjadikan perangkatnya sebagai router untuk meneruskan paket data dan menjamin bahwa paket berhasil dikirimkan dari sumber ke tujuan. MANET ini sangat cocok untuk diterapkan pada daerah yang belum memiliki infrastruktur komunikasi internet atau sebagai alat komunikasi darurat jika infrastruktur rusak.

Ada beberapa hal yang perlu dipertimbangkan dalam mengimplementasikan MANET, termasuk bagaimana cara menghubungkan satu mobile device (selanjutnya disebut node) dengan node lainnya diluar jangkauan wireless sehingga seringkali harus melewati beberapa node penghubung atau network multihop. Belum lagi, node pada MANET yang sifatnya dinamik turut mempengaruhi perubahan secara periodik topologi jaringan dan jalur transmisi, termasuk jika jarak antara node-node menjadi sangat besar, maka power pengiriman lemah, transimisi data menjadi rendah, delay dan kegagalan membaca jalur pengiriman tinggi, sehingga packet loss sering terjadi.

Perlu adanya standar routing protokol agar pengiriman data bisa dilakukan secara optimal. Salah satu alternatif protokol routing MANET yang banyak digunakan adalah AODV (Ad Hoc Demand Distance Vector). Berdasarkan beberapa penelitian, AODV unggul karena overhead routing yang rendah dan performa tinggi [1] [2] [3]. Akan tetapi, penentuan skema jalur utama hanya dengan menghitung minimal hop count, tanpa mempertimbangkan aspek lain seperti link throughput. Termasuk menyediakan jalur alternatif, ketika terdapat beberapa node penghubung yang mengalami kongesti atau kemacetan. Belum lagi pengiriman paket data dilakukan setelah pencarian jalur menjadi tidak efektif 
manakala jumlah node yang terhubung dalam jaringan $a d$ hoc berskala besar. Hal ini tidak hanya berimplikasi pada delay pengiriman yang meningkat, tetapi juga menghasilkan routing yang tidak valid, terlebih karena ada perubahan topologi saat pengiriman paket data dilakukan.

Oleh karena itu, dalam artikel ini akan diusulkan rancangan AODV dengan beberapa modifikasi dalam alur algoritmanya agar yang tidak hanya memiliki fitur skema routing jalur utama yang dipilih berdasarkan link throughput dan minimum hop count, tetapi juga mempertimbangkan penyediaan jalur alternatif saat link node mengalami kerusakan maupun saat antrian paket data melebihi kapasitas maksimal suatu node hingga status kongesti terjadi pada node, khususnya untuk mengurangi delay pengiriman paket yang rentan terjadi pada AODV konvensional.

\section{LANDASAN TEORI}

\section{A. Protokol Routing}

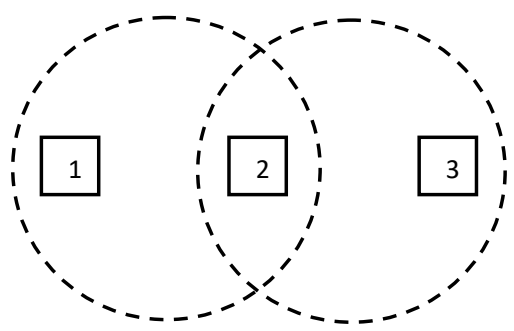

Gambar 1. Jaringan ad hoc dengan 3

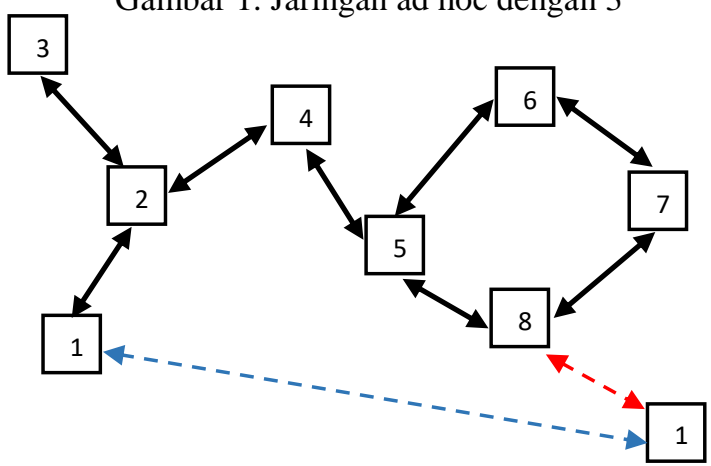

Gambar 2. Jaringan ad hoc dengan 8 node

Pada Gambar 1, terdapat tiga buah node, yang mana node- 1 berada di jangkauan transmisi node- 2 tetapi di luar jangkauan node-3. Node-2 dapat menjangkau node-1 dan node-3. Serta, node-3 berada di jangkauan transmisi node2 tetapi di luar jangkauan node-1. Sekarang jika node-1 dan node-3 ingin berkomunikasi satu sama lain, node tersebut harus memanfaatkan layanan node-2 untuk meneruskan komunikasinya.

Pada kenyataannya ad hoc multinode lebih rumit daripada contoh pada Gambar 1, karena nodenya tidak hanya 3, melainkan lebih seperti pada Gambar 2 yang terdapat 8 buah node. Awalnya jika node-1 ingin mengirimkan paket data ke node-7, maka jalur transmisinya sebagai berikut: $1 \rightarrow 2 \rightarrow 4 \rightarrow 5 \rightarrow 6 \rightarrow 7$. Apabila di tengah-tengah proses pengiriman sedang berlangsung, tiba-tiba node-1 bergerak mendekati dan berada dalam jangkauan yang sama dengan node- 8 , maka jalur transmisi berubah menjadi: $1 \rightarrow 8 \rightarrow 7$ dengan tetap menjaga agar tidak terjadi packet loss selama proses routing updating. Agar proses updating tersebut berjalan dengan baik, perlu adanya protokol routing. Protokol routing dalam MANET bukan hal yang sederhana seperti fix network, karena suatu protokol harus mampu mengatasi masalah multinode yang bisa saja bergerak setiap saat, sehingga node yang sudah terdeteksi sebelumnya tiba-tiba menghilang atau sebaliknya ada node-node baru bermunculan sehingga pemetaan jalur harus bisa diupdate secara periodik dalam protokol routing MANET. Protokol routing pada MANET dapat dibedakan menjadi dua yaitu protokol routing reaktif dan routing proaktif. Salah satu alternatif protokol routing yang sering digunakan pada MANET adalah AODV.

\section{B. AODV}

Protokol AODV (Ad Hoc on Demand Distance Vector) merupakan protokol reaktif yang dibangun berdasarkan permintaan routing dalam menentukan jalur hanya ketika node sumber ingin mengirimkan paket data ke node tujuan, dimana didalamnya terdapat penggabungan antara fitur routing discovery dan routing maintenance yang diambil dari DSR protokol, dan fitur hop by hop routing dan destination sequence number yang diambil dari DSDV protokol. AODV menggunakan RREQ (route request) dan RERR (route error) sebagai sinyal kontrol [4].

Proses routing pada AODV dibagi kedalam dua mekanisme, yakni discovery route dan maintenance route [5] [6].

\section{- Discovery Route}

Agar sebuah node sumber dapat mengirimkan data maupun melakukan komunikasi ke beberapa node tujuan, maka tidak hanya sekedar node sumber mengetahui IP (internet protocol) node tujuan, tetapi juga harus menginisialisasi jalur yang akan dilewati oleh paket data. Caranya melalui proses pencarian jalur, dimana node sumber melakukan broadcast RREQ (route request) ke semua node tetangga. Node yang mengetahui jalur ke penerima bisa dikatakan sebagai node penghubung atau router. Baik node penghubung maupun node tujuan akan menyimpan tabel routing baru yang dibawa oleh RREQ. Tabel routing baru ini berisi alamat node penghubung sebagai jalur menuju ke node penghubung lainnya atau node tujuan. Jika ada node yang mendapatkan pesan RREQ yang sama, maka pesan RREQ yang diterima terakhir itu akan dibuang. Selanjutnya node akan merespon pesan RREQ dengan meneruskan kembali ke node tetangga lainnya jika node tersebut bukan node tujuan. Akan tetapi jika node tujuan yang menerima pesan RREQ, maka selanjutnya node tersebut akan mengirimkan pesan balasan RREP (route reply) secara unicasting. Pesan RREP disalurkan sepanjang jalur yang dibentuk RREQ sebelumnya, melewati node-node yang memiliki jalur ke penerima. Hingga pesan RREP sampai ke node sumber, pesan ini berisi tentang IP pengirim, IP penerima, hop count (lompatan node yang dilewati), dan time to live (waktu pesan). Dengan RREP ini, secara sekuensial jalur end to end akan terbentuk sendiri antara node tujuan menuju node sumber. Jika jalur kadaluarsa atau tidak pernah digunakan, maka entri routing yang mengarahkan ke jalur tersebut otomatis akan terhapus dalam rentang waktu tertentu. 


\section{- Maintenance Route}

Saat jalur telah terbentuk, mekanisme kerja routing AODV bergantung pada masing-masing entri routing tabel node itu sendiri, sehingga tidak diperlukan informasi routing dari node penghubung. Melalui pesan HELLO broadcast yang dikirim secara periodik antar node bertugas untuk menginformasikan dan memastikan bahwa topologi link node di depannya tidak mengalami perubahan ataupun kerusakan. Apabila itu terjadi, maka node yang terhubung pada link tersebut akan mengirimkan pesan RERR (route error) ke node penghubung yang aktif sebagai pesan untuk menjelaskan bahwa link telah rusak. Proses tersebut secara relay akan terus dikirimkan sampai pesan error diterima oleh semua node aktif, termasuk sampai ke node sumber. Setelah menerima pesan ini, node akan menghapus semua jalur yang berisi node gagal. Selanjutnya, discovey route akan diaktifkan kembali dan node sumber harus mengirimkan ulang RREQ untuk menemukan jalur alternatif yang baru.

\section{METODE PENELITIAN}

Metode penelitian ini didasarkan pada penerapan metode SLR sebagai suatu cara untuk melakukan ulasan penelitian dengan melakukan klasifikasi dan perbandingan terhadap beberapa penelitian yang telah ada baik berupa artikel, jurnal, atau conference. SLR menjelaskan proses pencarian dokumen secara relevan dari pertanyaan penelitian yang diajukan. Penelitian ini memiliki tiga tahapan: (i) Rencana review yang mendefinisikan protokol review untuk menentukan pertanyaan penelitian. (ii) Implementasi dibutuhkan kriteria inklusi dan eksklusi untuk mendapatkan kriteria kata kunci utama yang berhubungan dengan pertanyaan penelitian. (iii) Dokumentasi yang bertujuan untuk memberikan informasi yang diperoleh dari setiap ulasan berupa ringkasan.

\section{A. Research Question (RQ)}

Research question digunakan untuk mendefinisikan kriteria atau atribut pertanyaan yang menjadi acuan kerangka pertanyaan. Pertanyaan utama pada studi literatur penelitian ini adalah sebagai berikut:

RQ1 : Bagaimana perkembangan dan prinsip kerja algoritma AODV yang sudah ada?

RQ2 : Bagaimana skema pencarian jalur pada desain Modifikasi AODV usulan?

RQ3 : Bagaimana skema pemeliharaan jalur pada desain Modifikasi AODV usulan?

\section{B. Proses Pencarian Pertanyaan}

Dari RQ diatas kemudian dicari kata kunci pertanyaan yang sesuai untuk studi literatur pada penelitian ini. Kata kunci yang dapat digunakan adalah MANET, AODV, dan Modifikasi AODV. Setelah mendefinisikan atribut/kata kunci untuk dijadikan kerangka acuan dalam menjawab RQ, langkah selanjutnya yaitu melakukan proses pencarian studi pustaka dengan menggunakan ekspresi operator logika AND, OR pada basis data jurnal seperti ScienceDirect, IEEE, Google Scholar.

\section{Kriteria Inklusi dan Eksklusi}

Untuk membatasi ruang lingkup pencarian maka dibutuhkan penyaringan kata kunci dengan menggunakan penyaringan berdasarkan kriteria inklusi sebagai berikut:

1) Fokus pada analisis modifikasi AODV.

2) Sumber dalam bahasa Inggris dan memberikan jawaban atas pertanyaan penelitian dan kata kunci penelitian

3) Publikasi literatur dalam bentuk jurnal atau conference yang diseleksi oleh penulis.

Untuk mempercepat pencarian, maka diperlukan suatu cara agar dapat mempersempit ruang lingkup pencarian yang mengabaikan literatur hasil penyaringan eksklusi dengan kondisi sebagai berikut:

1) Literatur yang menggunakan bahasa selain bahasa Inggris.

2) Literatur yang tidak terkait dengan pertanyaan dan kata kunci penelitian.

3) Sumber yang hanya memberikan informasi dalam bentuk abstrak.

4) Literatur ganda dari sumber pencarian.

\section{Ekstraksi Data dan Sintesis}

Selanjutnya adalah ekstraksi jurnal, conference secara manual yang ada kaitannya dengan judul, abstrak, kata kunci dan referensi yang sesuai dengan pertanyaan penelitian dan kata kunci penelitian. Penelitian yang dilakukan ini akan memberikan desain usulan modifikasi AODV berdasarkan review studi pustaka yang diperoleh dari sumber literatur yang sudah ada.

\section{E. Dokumentasi dan Validasi Hasil}

Kumpulan jurnal dan conference hasil ektraksi kemudian divalidasi dengan tujuan untuk mengetahui gambaran perkembangan algoritma modifikasi AODV yang kemudian dituangkan ke dalam desain usulan modifikasi AODV pada penelitian ini.

\section{IV.HASIL DAN PEMBAHASAN}

Setelah ditentukan kriteria inklusi dan eksklusi dan pemilihan jurnal berdasarkan abstrak yang dibaca maka diperoleh beberapa jurnal atau conference yang relevan untuk selanjutnya dikaji lebih lanjut dan dijadikan pembahasan penelitian. Adapun pemaparan hasil review yang menjawab RQ studi literatur penelitian ini dijabarkan sebagai berikut:

RQ1 : Bagaimana perkembangan dan prinsip kerja algoritma AODV yang sudah ada?

\section{Ide Awal Algoritma}

Pada AODV konvensional, paket data dikirimkan setelah pencarian jalur utama selesai. Hal tersebut menjadi masalah ketika node yang saling terhubung berskala besar, dimana paket data diminta menunggu dalam waktu yang lama hingga jalur utama selesai terbentuk. Hal ini tidak hanya berimplikasi pada delay pengiriman yang tinggi, tetapi juga menghasilkan jalur yang tidak valid, terlebih karena ada perubahan topologi saat pengiriman paket data dilakukan. AODV konvensional dalam memilih jalur utama routing ke node tujuan hanya berdasarkan minimum hop count, sehingga 
jalur alternatif lain yang hop count-nya lebih besar akan diabaikan. Padahal bisa jadi jalur yang hop count-nya besar, memiliki link throughput lebih baik bila dibandingkan dengan minimum hop count. Selain itu, jika jalur utama rusak maka jalur alternatif tersebut bisa digunakan, itupun harus melalui proses pencarian jalur kembali yang tentu akan meningkatkan delay pengiriman. Jalur sebuah node dikatakan terputus (host unreachable) jika daya node down, node rusak dan secara mobile node bergerak menjauhi jalur utama. Padahal gangguan jalur pada node juga bisa dikarenakan alur density antrian paket melebihi batas maksimal buffer size node yang berakibat pada kongesti, sehingga pengiriman mengalami RTO (request time out). Hal ini tidak menjadi pertimbangan dalam AODV konvensional, sehingga berakibat masih tingginya loss rate (kehilangan) paket data saat pengiriman berlangsung.

Oleh karena itu, algoritma AODV pendekatan baru yang diusulkan akan mengkombinasikan beberapa algoritma, seperti AODV_ODB, AODV_M, AODV_BRL, dan OLSR_RED sehingga diharapkan mampu mengurangi delay yang terjadi saat paket data harus menunggu jalur selesai terbentuk melalui penyisipan paket data pada pesan RREQ. Termasuk mempertimbangkan pencarian jalur terpendek dengan tidak mengabaikan beberapa jalur alternatif melalui pemilihan jalur berdasarkan perhitungan nilai throughput, dan pengalihan jalur jika terdapat status kongesti pada node penghubung.

\section{Pesan RREQ disisipkan Paket Data}

Salah satu kondisi delay yang terjadi pada AODV konvensional adalah saat paket data menungu dalam jangka waktu tertentu untuk dikirim selama proses pencarian jalur utama node sumber ke node tujuan. Berdasarkan penelitian yang telah dilakukan sebelumnya, delay tersebut dapat dikurangi melalui modifikasi pesan RREQ dengan pendekatan AODV_ODB. Konsep AODV_ODB [7] adalah saat menemukan link error, node akan melakukan broadcast sebuah paket header, yang tidak hanya berisi pesan RREQ, tetapi juga paket data. Artinya, ketika pesan RREQ menjangkau node tetangga bukan node tujuan, jalur baru terbentuk dan paket data juga diterima node tetangga, hingga paket di broadcast terus sampai ke node tujuan. Ketika paket header mencapai node tujuan, node tujuan akan mengirim RREP dan pada saat yang sama menerima paket data. Hal ini tidak hanya akan mempermudah pengaturan routing tetapi juga mengurangi delay pengiriman, karena paket data langsung dikirimkan saat pencarian jalur bersamaan dengan pengiriman pesan RREQ.

\section{Inisialisasi Jalur berdasarkan Link Throughput}

Spesifikasi bandwidth, daya, dan stabilitas sinyal yang berbeda pada masing-masing node atau peralatan wireless mobile erat kaitannya dengan link throughput yang bisa dilewati untuk pengiriman paket, sehingga nilai throughput dari link bottleneck (link dengan throughput terendah di antara semua link dalam rute tertentu) dapat dianggap sebagai nilai throughput untuk jalur tertentu yang menjadi acuan utama dalam menentukan skema routing AODV, selain dengan minimum hop count. Nilai
Throughput adalah bandwidth aktual jalur pengiriman paket dengan rumus dalam persamaan 1 berikut ini.

$$
\text { Throughput }=\frac{\text { ukuran_paket }(\text { bit })}{\text { waktu_paket_diterima }(\operatorname{det} i k)}[8]
$$

Penelitian yang pernah dilakukan berkaitan penentuan jalur berdasarkan throughput menggunakan algoritma AODV_M. Konsep AODV_M [9] menyisipkan nilai throughput node sumber pada paket RREQ yang diteruskan ke node tetangga yang kemudian dibandingkan dengan link throughput node tetangga yang ada. Jika link throughput node tetangga lebih kecil dari nilai throughput yang dibawa paket RREQ, maka nilai throughput paket RREQ diubah dan digantikan dengan nilai link throughput node tetangga. Selanjutnya paket RREQ membawa nilai throughput yang baru diteruskan ke node tetangga lainnya dan jumlah hop count bertambah satu.

Jika sebuah paket RREQ dengan destination sequence number yang sama, tapi berasal dari jalur yang berbeda berhasil diterima oleh node tujuan. Maka untuk algoritma AODV konvensional, node tersebut hanya akan memilih paket dari jalur dengan hop count paling minimal atau paket yang terlebih dahulu diterima dan melakukan drop terhadap paket yang baru datang. Sedangkan dengan algoritma AODV_M, nilai throughput paket RREQ yang baru datang dibandingkan dengan nilai throughput paket RREQ sebelumnya. Setelah dibandingkan, nilai throughput paket RREQ yang paling besar itulah yang kemudian akan diteruskan ke node selanjutnya. Akan tetapi, jika ternyata perbandingan nilai throughput menghasilkan nilai yang sama, maka baru jalur dengan minimum hop count yang dipilih. Begitu seterusnya, hingga paket RREQ sampai ke node tujuan. Kemudian node tujuan mengirimkan RREP dengan cara yang sama seperti pengiriman paket RREQ, dengan membandingkan nilai throughput RREP paket antar node yang telah dilewati paket RREQ sebelumnya, sehingga terbentuk jalur end-to-end antara node sumber ke node tujuan dengan memilih node penghubung sebagai jalur yang memiliki throughput paling besar.

\section{Backup Jalur dengan LHF}

Dalam AODV konvensional, node sumber mengirimkan data dan melakukan komunikasi ke node tujuan dengan memanfaatkan sebuah jalur tunggal yang terbentuk secara end-to-end melalui node-node penghubung berdasarkan minimum hop count. Jalur tunggal yang dibangun akan memiliki kendala ketika node penghubung rusak, sehingga inisialisasi jalur harus diulang lagi, yang pencariannya dimulai dari node sumber ke node tujuan. AODV_BRL (Backup Route with LHF) merupakan satu dari sekian banyaknya algoritma routing guna mencari jalur alternatif pengiriman paket data. AODV_BRL [10] mengkombinasikan teknik backup jalur dengan penambahan sebuah ERT (Extended Routing Table) yang di broadcast bersamaan dengan pesan RREQ. Ketika node tujuan mendapatkan pesan RREQ dari beberapa jalur, maka node tujuan mengirimkan paket RREP dan ERT secara multicast ke node penghubung hingga sampai ke node sumber, sehingga ada beberapa jalur alternatif yang dapat terbentuk dari node sumber ke 


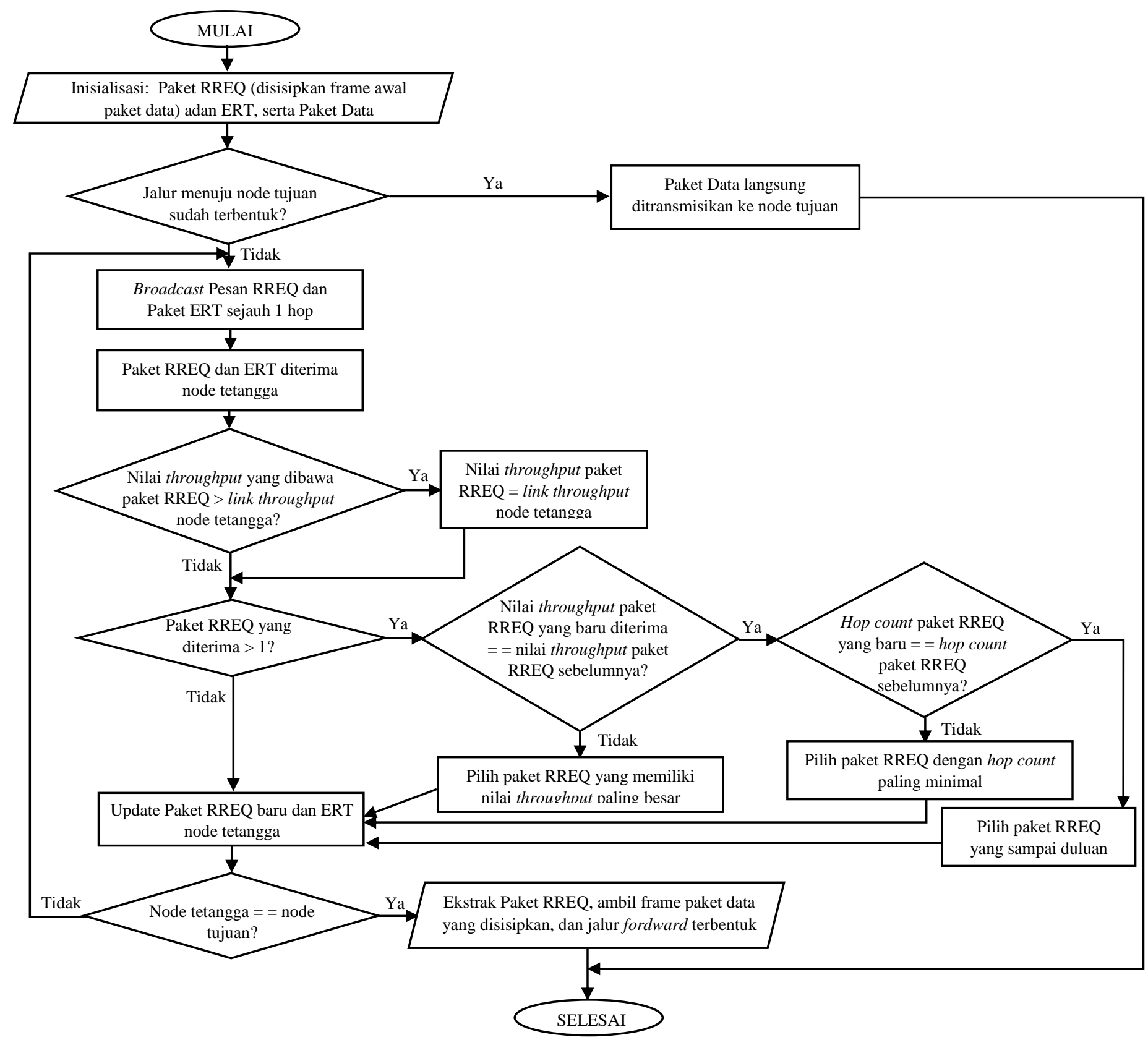

Gambar 3. Discovery Forwarding Routes

node tujuan, tidak hanya jalur utama yang hanya berdasarkan minimum hop count. Selain jalur alternatif yang dibangun oleh paket RREP, struktur mesh akan dibuat dengan mentransmisikan secara broadcast Extended Hello Message dari sebuah node tetangga ke node tetangga lainnya yang masih dalam jangkauan satu hop. Hello message akan dikirimkan setiap interval waktu $1,000 \mathrm{~ms}$. Proses ini untuk mengetahui mana saja node tetangga yang masih aktif dan mengupdate ERT yang berasal dari node tetangga.

Jika dalam jangkauan satu hop, hello message mendeteksi adanya link yang rusak, maka proses pencarian jalur tidak diinisialisasi ulang dari node sumber, seperti pada AODV konvensional. Melainkan perbaikan link berdasarkan metode LHF yakni mensubstitusi alamat routing node yang rusak dengan alamat routing node penghubung baru yang lain yang punya jalur ke node tujuan pada ERT sebuah downstream node. Jika ternyata dari ERT downstream node tidak ditemukan jalur alternatif, maka pengecekan dilakukan kembali dengan mengirimkan BRRQ (backup route request) dari downstream node ke node tetangganya. Jika terdapat node tetangga yang punya jalur ke node tujuan, maka node tersebut mengirimkan pesan balasan BRRP (backup route reply) dan node tersebut menjadi jalur alternatif yang baru. Hal ini tentu akan mengurangi overhead dan delay saat perbaikan link, karena pencarian jalur tidak diinisialisasi ulang dari node sumber.

\section{Status Kongesti sebagai Pertimbangan Link Error}

Link sebuah node dalam MANET dapat dikatakan terputus, jika node rusak, mati, dan diluar jangkauan. Padahal penyebab terputusnya link, juga bisa karena meningkatnya jumlah queue (antrian) melebihi buffer node maksimal yang bisa mengakibatkan kongesti (kemacetan). Penelitian yang pernah dilakukan untuk mendeteksi adanya kongesti adalah penerapan algoritma RED (Random Early Detection) pada protokol AODV 
[11] dan OLSR_RED [12]. RED merupakan algoritma active queue management (AQM). RED menghitung ratarata ukuran queue yang masuk ke node dengan memberikan nilai Threshold (ambang bata). Rata-rata ukuran queue dibandingkan untuk dua nilai Threshold, minimum Threshold dan maksimum Threshold [13]. Rumus nilai Threshold yang digunakan dapat dilihat pada persamaan 2 dan 3.

$$
\begin{aligned}
& \operatorname{Min}_{\text {Thr }}=0,25 \times \text { Buffer }_{\text {size }} \\
& \operatorname{Max}_{\text {Thr }}=3 \times \operatorname{Min}_{\text {Thr }} \\
& A v Q=\left(\left(1-w_{q}\right) \times A v g\right)+\left(\operatorname{Cur}_{\text {Que }} \times w_{q}\right) \\
& \text { Status }_{\text {Que }}=C u r_{\text {Que }}-A v Q
\end{aligned}
$$

Min $_{T h r}$ adalah nilai batas minimum Threshold. Max Thr adalah nilai batas maksimum Threshold. $A v Q$ adalah nilai rata-rata dari ukuran paket antrian (persamaan 4). $w_{q}$ adalah bobot (weigth) antrian dengan nilai konstan 0,002 . Cur $_{\text {Que }}$ adalah ukuran paket antrian saat ini, sedangkan Status $_{Q u e}$ merupakan kondisi dari nilai aktual antrian (persamaan 5). Ukuran antrian semakin berkurang manakala paket data yang datang dalam jaringan akan memenuhi antrian. Hasil perbandingan Status Que akan diklasifikasikan ke dalam nilai CC. Jika Status Que kurang dari $\mathrm{Min}_{T h r}$, maka node diklasifikasikan ke area aman dari kongesti (Area I) dengan nilai CC $=000$. Apabila Status Que lebih dari Min $_{T h r}$ dan Cur $_{Q u e}$ kurang dari Max ${ }_{T h r}$, maka node diklasifikasikan ke dalam area mendekati kongesti (Area II) dengan nilai CC $=001$, sedangkan jika Cur ${ }_{\text {Que }}$ lebih dari $\operatorname{Max}_{\text {Thr }}$ maka node diklasifikasikan ke dalam area dalam keadaan kongesti (Area III) dengan nilai $\mathrm{CC}=010$.

Jika sebuah node penghubung memiliki nilai $\mathrm{CC}=010$, artinya link error dan (ng)de tersebut segera mentransmisikan CSP (Congestion Status Packet) sejauh satu hop ke node tetangganya. Pesan CSP yang dikirim berisi nilai status kongesti $(\mathrm{CC}(4)$ dan parameter routing (Source S, Destination D, Hop Count hop, Sequence Number Seq, Neighbors Information N_list). Node tetangga yang menerima CSP akan mencari jalur alternatif dan menghapus link yang error dari ERT-nya.

\section{RQ2: Bagaimana skema pencarian jalur pada desain Modifikasi AODV usulan?}

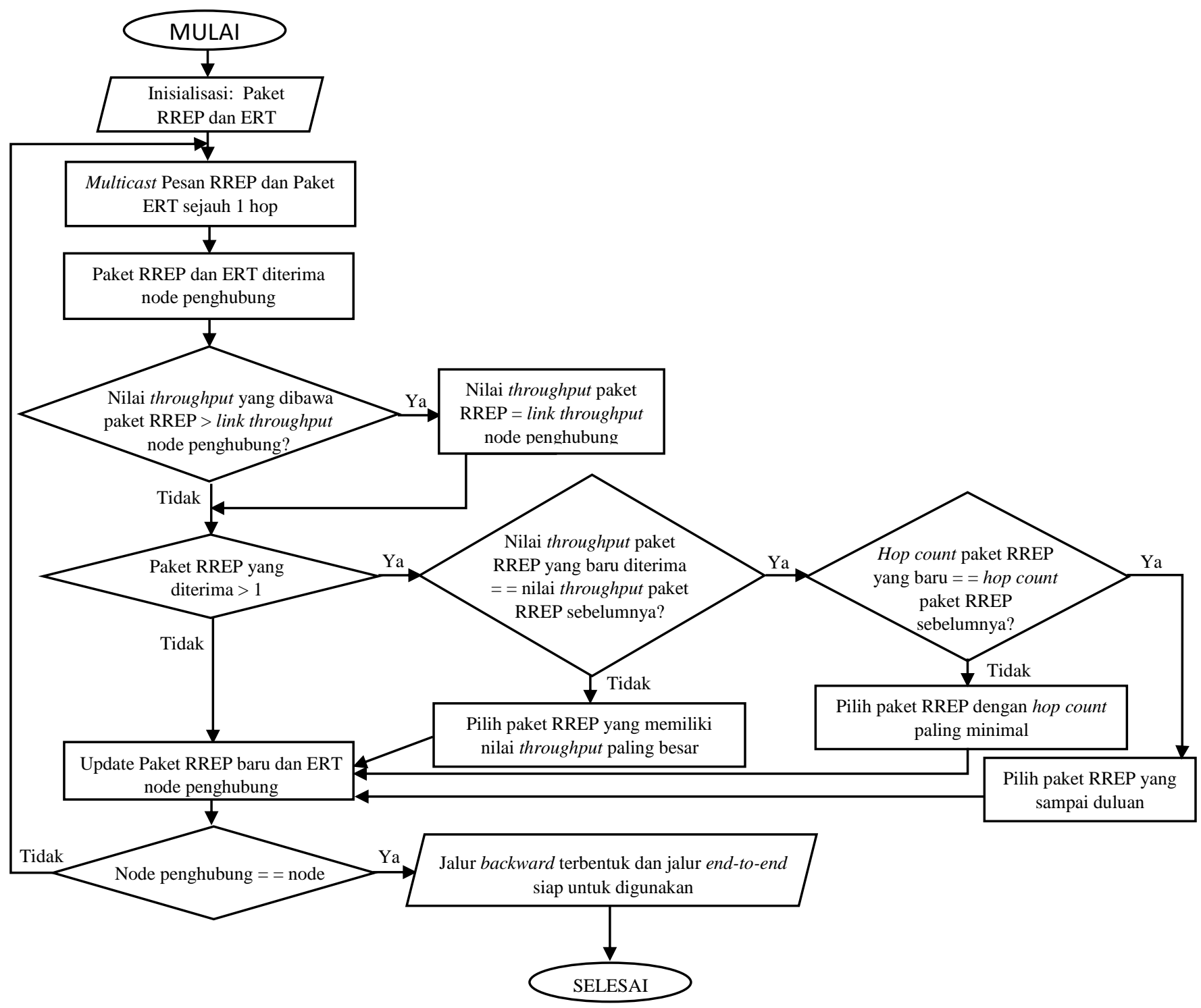

Gambar 4. Discovery Backwarding Routes 
Setelah mempelajari perkembangan dan prinsip kerja algoritma AODV yang telah ada, maka kemudian didesain skema pencarian jalur (discovery route) algoritma AODV modifikasi usulan akan dibagi menjadi 2, yaitu discovery forwarding route dan backwarding route. Terdapat penambahan paket Extended Routing Table (ERT) yang ditransmisikan bersamaan dengan pesan RREQ dan RREP saat pencarian jalur. Pesan RREQ dan RREP juga dimodifikasi dengan adanya penambahan field throughput. Selain itu, pada pesan RREQ disisipkan frame awal paket data. Alur algoritma protokolnya dapat dilihat pada Gambar 3 dan 4 .

Fase discovery forwarding route (lihat Gambar 3) akan diaktifkan jika ada request (permintaan) pengiriman data dari suatu node sumber ke node tujuan. Permintaan itu menginisialisasi paket data, pesan RREQ (route request), dan paket ERT (extended routing table). Jika node sumber gagal mengidentifikasi jalur ke node tujuan, maka node sumber akan mencari jalur dengan mengirimkan pesan RREQ dan paket ERT sejauh 1 hop. Untuk pesan RREQ, terdapat penambahan header dengan menyisipkan frame paket data dan penambahan nilai field throughput. Selanjutnya, pesan RREQ dan paket ERT diterima oleh node tetangga. Pesan RREQ yang melakukan pengecekan apakah node tetangga adalah node tujuan. Jika tidak, maka pesan RREQ dan paket ERT diteruskan kembali ke node tetangga berikutnya sejauh 1 hop. Akan tetapi, sebelumnya nilai throughput yang dibawa oleh pesan RREQ akan dibandingkan terlebih dahulu dengan link throughput aktual node tetangga. Jika link throughput node tetangga lebih kecil dari nilai yang dibawa pesan RREQ, maka kemudian pesan RREQ mengupdate nilai throughput-nya sama dengan link throughput node tetangga. Dimungkinkan node tetangga menerima pesan RREQ dengan ID yang sama lebih dari 1 , karena pesan yang dikirimkan bisa jadi berasal dari beberapa node tetangga sebelumnya. Jika hal ini terjadi, maka node tetangga memilih pesan RREQ yang membawa nilai throughput paling besar. Jika nilai throughput sama, maka node tetangga memilih pesan RREQ yang memiliki jumlah hop count paling minimal. Jika jumlah hop count sama, maka node tetangga memilih pesan RREQ yang duluan sampai untuk diteruskan ke node tetangga berikutnya. Begitu seterusnya langkahlangkah tersebut dilakukan hingga pesan RREQ dan paket ERT sampai ke node tujuan. Di node tujuan, pesan RREQ diekstrak dan frame data diterima node tujuan. Selanjutnya node tujuan akan mengirimkan pesan RREP (route reply) secara multicast mundur ke node sebelumnya yang menjadi node penghubung karena telah memiliki peta jalur.

Pada fase discovery backwarding route (lihat gambar 4), pesan RREP dikirimkan sejauh 1 hop ke node sebelumnya yang telah mengirimkan pesan RREQ ke node tujuan. Hampir sama dengan fase forwarding route, di fase ini, pesan RREP yang melakukan pengecekan apakah yang menerima pesan ini adalah node sumber. Jika tidak, maka pesan RREP dan paket ERT diteruskan ke node penghubung berikutnya. Akan tetapi, sebelumnya nilai throughput yang dibawa oleh pesan RREP akan dibandingkan terlebih dahulu dengan link throughput aktual node penghubung. Jika link throughput node penghubung lebih kecil dari nilai yang dibawa pesan RREP, maka kemudian pesan RREP mengupdate nilai throughput-nya sama dengan link throughput node penghubung. Dimungkinkan node penghubung menerima pesan RREP dengan ID yang sama lebih dari 1, karena pesan yang dikirimkan bisa jadi berasal dari beberapa node penghubung sebelumnya. Jika hal ini terjadi, maka node penghubung memilih pesan RREP yang membawa nilai throughput paling besar. Jika nilai throughput sama, maka node penghubung memilih pesan RREP yang memiliki jumlah hop count paling minimal. Jika jumlah hop count sama, maka node penghubung memilih pesan RREP yang duluan sampai untuk diteruskan ke node penghubung berikutnya. Looping langkah-langkah tersebut hingga pesan RREP dan paket ERT sampai ke node sumber. Ketika pesan RREP sampai node sumber, maka saat itu jalur routing telah terbentuk, dimana setiap node penghubung memiliki peta jalur berdasarkan tabel ERT dan siap digunakan untuk pengiriman paket data selanjutnya.

\section{RQ3 : Bagaimana skema pemeliharaan jalur pada desain Modifikasi AODV usulan?}

Berdasarkan studi literatur yang telah dilakukan, maka ditemukan tiga faktor utama yang mengakibatkan link dalam jaringan MANET terputus, diantaranya kerusakan fisik jalur node, mobilitas node, dan kongesti node. Untuk kerusakan fisik dan mobilitas node, pengecekan dilakukan dengan mengirimkan hello message dengan TTL $=1$ detik ke node tetangga sejauh 1 hop, jika terdapat node tetangga yang tidak membalas pesan, maka peta routing ERT yang mengarah ke node tersebut akan dihapus. Untuk kongesti, pengecekan dilakukan dengan mengirimkan pesan CSP oleh node yang sedang mengalami kongesti ke node tetangganya sejauh 1 hop yang kemudian direspon oleh node tetangga dengan menghapus peta routing ERT yang mengarah ke node kongesti. Berikut skema pencarian jalur alternatif saat kerusakan fisik atau mobilitas node terjadi.

Berdasarkan Gambar 5, diketahui pemilihan jalur awal untuk pengiriman paket data adalah $\mathrm{A} \rightarrow \mathrm{B} \rightarrow \mathrm{C} \rightarrow \mathrm{D} \rightarrow \mathrm{F} \rightarrow \mathrm{G} \rightarrow \mathrm{H}$, dengan mempertimbangkan link throughput dan minimum hop count. Pada saat tertentu, kemudian node D bergerak menjauhi spot, sehingga jalur utama routing terputus. Downstream node dari node D adalah node $\mathrm{C}$ yang awalnya memiliki ERT sebagai berikut:

Tabel I

Extended Routing Table untuk Node C

\begin{tabular}{|c|c|c|c|c|c|c|c|}
\hline Entri & Tujuan & $\begin{array}{c}\text { Next } \\
\text { hop }^{1} \\
(\mathbf{C})\end{array}$ & $\begin{array}{c}\mathbf{N e x t}_{\text {hop }^{2}} \\
(\mathbf{C})\end{array}$ & $\begin{array}{c}\text { Next } \\
\text { hop }^{\mathbf{3}} \\
(\mathbf{C})\end{array}$ & $\cdots$ & $\begin{array}{c}\text { Next } \\
\text { hop } \\
\text { (C) }\end{array}$ & Throughput \\
\hline$\cdots$ & $\cdots$ & $\cdots$ & $\cdots$ & $\cdots$ & $\cdots$ & $\cdots$ & $\cdots$ \\
\hline $\mathrm{i}-1$ & $\mathrm{~A}$ & $\mathrm{~B}$ & $\cdots$ & $\cdots$ & $\cdots$ & $\cdots$ & $5,5 \mathrm{Mbps}$ \\
\hline $\mathrm{I}$ & $\mathrm{H}$ & $\mathrm{D}$ & $\mathrm{F}$ & $\mathrm{G}$ & $\cdots$ & $\cdots$ & $1 \mathrm{Mbps}$ \\
\hline$\cdots$ & $\cdots$ & $\cdots$ & $\cdots$ & $\cdots$ & $\cdots$ & $\cdots$ & $\cdots$ \\
\hline
\end{tabular}




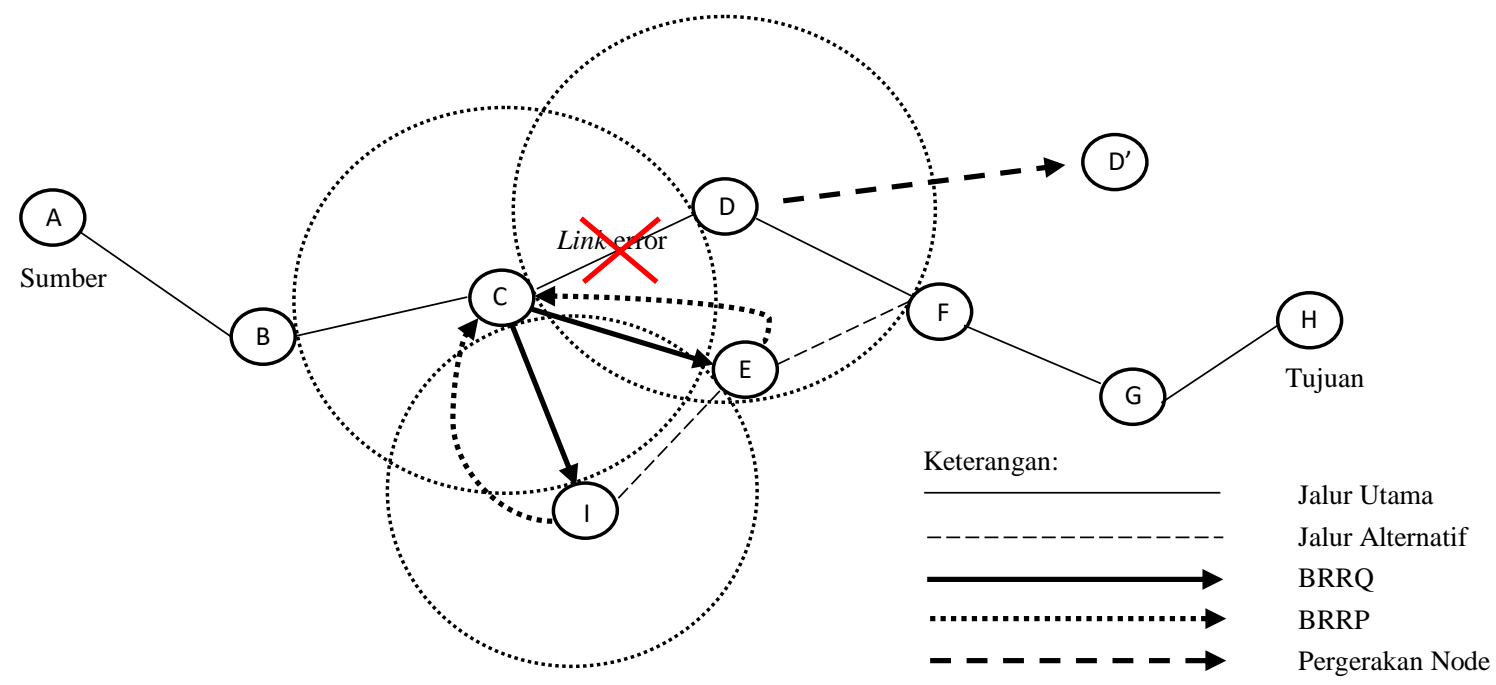

Gambar 5. Proses transmisi pesan BRREQ untuk mencari jalur alternatif ketika link error

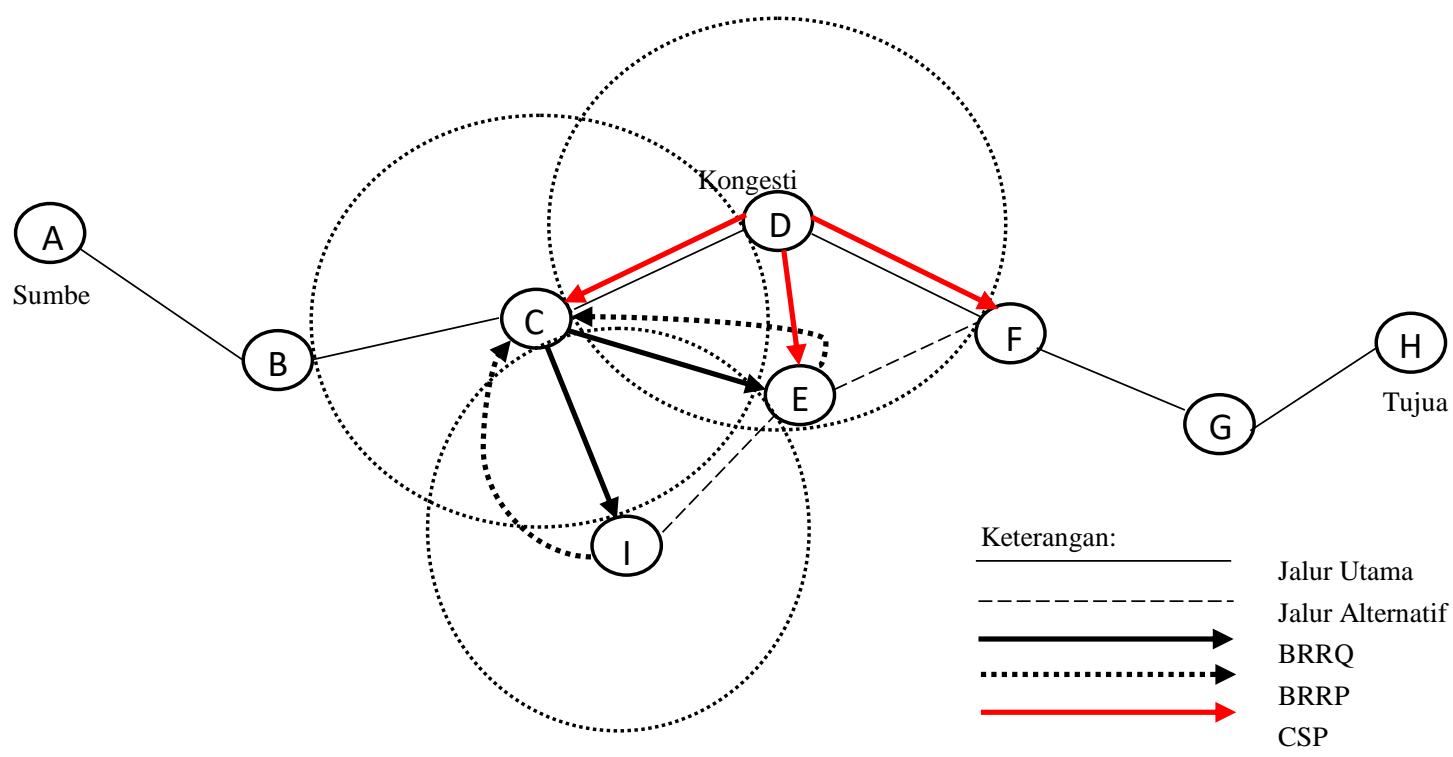

Gambar 6. Skema pemeliharaan jalur saat node sedang mengalami kongesti

Saat pengiriman paket data atau saat hello message ditransmisikan, ternyata node $\mathrm{C}$ mendeteksi adanya error link di depannya, maka node $\mathrm{C}$ memilih jalur alternatif lain berdasarkan ERT miliknya. Namun, jika ERT node C tidak menyediakan jalur alternatif, maka node $\mathrm{C}$ mentransmisikan secara broadcast pesan BRRQ sejauh 1 hop ke node tetangganya, yaitu node E dan I. Pesan ini kemudian direspon oleh node $\mathrm{E}$ dan I yang memiliki jalur ke node tujuan. Responsi berupa pengiriman pesan balasan BRRP dan ERT node tetangga. Jika node C mendapatkan pesan BRRP lebih besar dari 1, maka node $\mathrm{C}$ memilih jalur alternatif dengan throughput paling besar, Jika throughput sama, maka node $\mathrm{C}$ memilih jalur alternatif yang jumlah hop-nya paling minimal. Jika throughput dan hop sama, maka node $\mathrm{C}$ memilih jalur alternatif berdasarkan pesan BRRP mana yang sampai duluan.

Misal node E memiliki jalur throughput yang tinggi dan hop count paling minimal, maka node E yang menjadi node penghubung alternatif menggantikan node $\mathrm{D}$, sehingga data ERT node $\mathrm{E}$, yakni $\mathrm{F} \rightarrow \mathrm{G} \rightarrow \mathrm{H}$ disubstitusikan ke tabel data ERT node $\mathrm{C}$, tentu dengan penambahan node $\mathrm{E}$ sebagai next hop $^{l}$ untuk node $\mathrm{C}$, sehingga jalur alternatif terbentuk menjadi $\mathrm{A} \rightarrow \mathrm{B} \rightarrow \mathrm{C} \rightarrow \mathbf{E} \rightarrow \mathrm{F} \rightarrow \mathrm{G} \rightarrow \mathrm{H}$. Berikut adalah ERT node $\mathrm{C}$ setelah diupdate:

Tabel II

Extended Routing Table untuk Node C setelah di update

\begin{tabular}{|c|c|c|c|c|c|c|c|}
\hline Entri & Tujuan & $\begin{array}{c}\text { Next } \\
\text { hop }^{1} \\
(\mathbf{C})\end{array}$ & $\begin{array}{c}\text { Next } \\
\text { hop }^{2} \\
(\mathbf{C})\end{array}$ & $\begin{array}{c}\text { Next } \\
\text { hop }^{3} \\
(\mathbf{C})\end{array}$ & $\cdots$ & $\begin{array}{c}\text { Next } \\
\text { hop } \\
(\mathbf{C})\end{array}$ & Throughput \\
\hline$\cdots$ & $\cdots$ & $\cdots$ & $\cdots$ & $\cdots$ & $\cdots$ & $\cdots$ & $\cdots$ \\
\hline i-1 & A & B & $\cdots$ & $\cdots$ & $\cdots$ & $\cdots$ & 5,5 Mbps \\
\hline I & H & E & F & G & $\cdots$ & $\cdots$ & 5,5 Mbps \\
\hline$\cdots$ & $\cdots$ & $\cdots$ & $\cdots$ & $\cdots$ & $\cdots$ & $\cdots$ & $\cdots$ \\
\hline
\end{tabular}

Selanjutnya, berikut skema pemeliharaan jalur menggunakan jalur alternatif saat node sedang mengalami kongesti dapat dilihat pada Gambar 6. Misal pada node D terjadi kondisi penumpukan antrian paket data, dimana Status Que antrian paket lebih besar dari Max Thr buffer node D, maka node $\mathrm{D}$ dikategorikan sebagai node kongesti, dengan nilai $\mathrm{CC}=010$. Node D segera mengirimkan CSP (Congestion Status Packet) ke node 
tetangganya sejauh 1 hop, yakni node $\mathrm{C}$, E, dan $\mathrm{F}$. Kemudian node $\mathrm{C}$, E, dan $\mathrm{F}$ mengupdate ERT mereka dengan menghapus routing yang melewati hop node D. Jika ternyata setelah penghapusan routing, node $\mathrm{C}$ tidak menemukan jalur ke node tujuan, maka skema pencarian jalur alternatif menggunakan cara yang sama, seperti ketika pencarian jalur dilakukan saat kerusakan fisik atau mobilitas node terjadi.

\section{KESIMPULAN DAN SARAN}

Untuk pencarian jalur pada desain modifikasi AODV yang diusulkan penelitian ini, selain mempertimbangkan minimum hop count, juga dipertimbangkan jalur throughput yang bisa dilewati untuk pemrosesan seleksi jalur. Selain itu, pencarian jalur dilakukan dengan mengirimkan pesan RREQ yang disisipi frame paket data, serta mengirimkan paket ERT (Extended Routing Table) untuk mengupdate tabel ERT untuk setiap node yang telah dilewati. Untuk pemeliharaan jalur, ada dua kondisi yang dipertimbangkan. Kondisi pertama saat node mengidentifikasi node tetangganya yang rusak saat pengiriman paket data berlangsung maupun melalui pengiriman pesan hello message. Jika ditemukan node rusak sejauh 1 hop, maka routing yang mengarah ke node tersebut akan dihapus. Kondisi kedua saat node sedang mengalami density (kepadatan) jalur diakibatkan antrian pengiriman paket yang mendekati kapasitas maksimal buffer node, node tersebut kemudian mengirimkan CSP (Congestion Status Packet) ke node tetangganya sejauh 1 hop. Node yang menerima CSP kemudian mengalihkan jalur ke routing alternatif lain dan menghapus routing yang mengarah ke node yang sedang kongesti. Kedua kondisi tersebut mengakibatkan jalur utama terputus, sehingga diperlukan pencarian jalur alternatif. Untuk pencarian jalur routing alternatif itu sendiri tidak dilakukan dengan menginisialisasi ulang dari node sumber ke node tujuan, melainkan cukup dengan pertukaran pesan BRRQ dan BRRP di sekitaran node penghubung. Jika alternatif routing ditemukan dari data routing node tetangga tertentu, maka node penghubung cukup mensubtitusi data routing yang lama dengan data routing yang berasal dari node tetangga tersebut pada tabel ERT-nya.

Saran untuk penelitian selanjutnya adalah hasil desain rancangan usulan penelitian ini dapat diujicobakan ke dalam simulasi skala lab untuk kemudian dilakukan penilaian performansi dengan membandingkan nilai PDR, throughput, overall routing traffic, dan overall end-to-end delay terhadap data kontrolnya, yaitu AODV_BRL dan AODV konvensional. Algoritma diterapkan dalam skenario yang sama pada software simulasi OPNET Modeler 16.0. Diharapkan dengan perbandingan ini, algoritma AODV modifikasi baru menghasilkan performa yang lebih baik daripada AODV konvensional.

\section{REFERENSI}

[1] R. F. Sari, A. Syarif and B. Budiarjo, "Analisis Kinerja Protokol Routing AODV Pada Jaringan Ad Hoc Hybrid: Perbandingan Hasil Simulasi Dengan NS-2 dan Implementasi Pada Testbed dengan PDA," Makara, Teknologi, vol. 12, no. 1, pp. 7-18, 2008.

[2] S. Mittal and P. Kaur, "Performance Comparison of AODV, DSR, and ZRP Routing Protocols in MANET'S," in International Conference on Advances in Computing, Control, and Telecommunication Technologies, 2009.

[3] A. B. Malany, V. S. Dhulipala and R. M. Chandrasekaran, "Throughput and Delay Comparison of MANET Routing Protocols," Int. J. Open Problems Compt. Math, vol. 2, no. 3, pp. 461-468, 2009.

[4] C. E. Perkins and E. M. Royer, "Ad Hoc Demand Distance Vector Routing," in Proc. IEEE Symp. The 2th IEEE Workshop on Mobile Systems and Application, 1999.

[5] E. M. Reyer, "A Review of Current Routing Protocols for Ad Hoc Mobile Wireless Networks," in IEEE Personal Communication.

[6] H. Yang and Z.-y. Li, "Simulation and Analysis of a Modified AODV Routing Protocols," in International Conference on Computer Science and Network Technology, 2011.

[7] B. LI, Y. Liu and G. Chu, "Optimized AODV Routing Protocol for Vehicular Ad Hoc Networks," in IEEE, 2010.

[8] E. S. Dewo, Bandwidth dan Throughput, IlmuKomputer.com, 2003.

[9] L. U. Khan, S. A. Mahmud, M. H. Zafar, G. M. Khan and H. S. Al-Raweshidy, "M-AODV: Modified Ad Hoc Ondemand Distance Vector Routing Scheme," in 9th International Symposium on Communication Systems, Networks \& Digital Sign (CSNDSP), 2014.

[10] L. Yujun and H. Lincheng, "The Research on an AODVBRL to Increase Reliability and Reduce Routing Overhead in Manet," in International Conference on Computer Application and System Modeling (ICCASM), 2010.

[11] S. T. Kumaran and V. Sankaranarayanan, "Early Congestion Detection and Adaptive Routing in MANET," Egyptian Informatics Journal, vol. 12, no. 3, pp. 165-175, 2011.

[12] I. N. B. Hartawan and W. Wibisono, "Mekanisme Pemilihan MPR dengan Congestion Detection dalam OLSR Pada MANET," Jurnal Ilmiah Ilmu Komputer Universitas Udayana, vol. 6, no. 2, pp. 11-17, 2013.

[13] S. Floyd and V. Jacobson, "Random Early Detection Gateways for Congestion Avoidance," IEEE/ACM Transactions Networking, vol. 1, no. 4, pp. 397-413, 1993.

[14] Y. Wang, Y. Zhou*, Y. Yu, Z. Wang and S. Du, "ADAODV: A Improved Routing Protocol Based on Network Mobility and Route Hops," 2012.

[15] C. T. Cuong, V. T. Tu and N. T. Hai, "MAR-AODV: Innovative Routing Algorithm in MANET based on Mobile Agent," in 27th International Conference on Advanced Information Networking and Applications Workshops, 2013. 